\title{
DETERMINAÇÃO DA MATERNIDADE NA GESTAÇÃO POR SUBSTITUIÇÃO
}

\author{
DETERMINATION OF MATERNITY IN SUBSTITUTION MANAGEMENT
}

\author{
Kênia Rodrigues de Oliveira ${ }^{1}$ \\ Maxuel Pereira Dias ${ }^{2}$
}

\section{RESUMO}

O presente artigo trata da aferição da maternidade nos casos de gestação em útero alheio. No Brasil vigora a presunção de que a maternidade é certa, sendo indicada através de sinais externos, como a gravidez e o parto. Ocorre que na gravidez por substituição a parturiente, não necessariamente será a mãe. Assim, inquire-se como é determinada a maternidade na gestação em útero alheio, se no Brasil vigora a presunção de maternidade pelo parto? Quanto aos objetivos, busca-se traçar um panorama a respeito das técnicas de reprodução assistidas, enfatizando o tratamento legal de tais procedimentos. Após, almeja-se explicar a técnica da gestação em útero alheio, analisando sua legitimidade diante da atual sistemática constitucional brasileira. Por fim, procura-se a compreensão de como se dá a aferição da maternidade na gestação por substituição, explicitando as posições em diferentes sentidos. A metodologia de pesquisa será a vertente jurídico-sociológica, servindo-se do raciocínio dialético, através do procedimento de teses e antíteses, visando chegar à síntese que será a resposta para o problema jurídico. Quanto aos resultados alcançados, percebeu-se que prevalece 0 entendimento de que a aferição da maternidade nos casos de maternidade por substituição deve ser conferida para quem for o detentor do projeto parental, havendo relativização da

\footnotetext{
${ }^{1}$ Mestre em Direito pelo Centro Universitário de Brasília (UniCEUB). Especialista em Direito do Trabalho e Processual do Trabalho pelo Centro Universitário de Anápolis (UniEVANGÉLICA), e em Direito Penal pela Universidade Federal de Goiás (UFG). Graduada em Direito pelo Centro Universitário de Anápolis (UniEVANGÉLICA). Docente universitária desde agosto de 2006 até o presente. Professora de Direito Civil (Família, Sucessões, Parte Geral e Contratos), Direito Constitucional e Direito Processual Civil na Faculdade Evangélica de Goianésia desde o ano de 2008, até o presente. Professora de Pós-Graduação pelo Centro Universitário de Anápolis (UniEVANGÉLICA). Analista Judiciária do Tribunal de Justiça do Estado de Goiás, desde 2000, lotada na Vara da Infância e Juventude e 1ํ Cível. Membro do Instituto Brasileiro de Direito de Família - IBDFAM. ORCID: https://orcid.org/0000-0003-0410-7561.

2 Graduando do Curso de Direito da Faculdade Evangélica de Goianésia (FACEG). Assistente Administrativo lotado no Gabinete da Vara Criminal da Comarca de Goianésia (GO). Facilitador de Círculos de Construção de Paz certificado pela Escola Judicial de Goiás (EJUG). ORCID: https://orcid.org/0000-0002-7959-4643.
} 
presunção de maternidade. No entanto, a falta de uma norma específica para tal situação acarreta considerável insegurança jurídica.

PALAVRAS-CHAVE: Aferição da filiação; Gestação em útero alheio; Maternidade.

\begin{abstract}
This article deals with the measurement of motherhood in cases of gestation in the uterus of others. In Brazil there is a presumption that maternity is certain, being indicated through external signs, such as pregnancy and childbirth. It occurs that in pregnancy by replacement the parturient, it will not necessarily be the mother. So, ask yourself how is maternity determined in gestation in another's womb, if in Brazil there is a presumption of maternity through childbirth? With regard to the objectives, it is sought to outline an overview of assisted reproduction techniques, emphasizing the legal treatment of such procedures. Afterwards, it is hoped to explain the gestational technique in the uterus of others, analyzing its legitimacy before the current Brazilian constitutional system. Finally, we seek the understanding of how gauging of motherhood occurs in gestation by substitution, explaining the positions in different senses. The research methodology will be the juridical-sociological aspect, using the dialectical reasoning, through the procedure of theses and antitheses, aiming at reaching the synthesis that will be the answer to the legal problem. Regarding the results achieved, it was noticed that the understanding prevails that the verification of maternity in cases of maternity by substitution should be conferred for whoever is the holder of the parental project, with relativization of the presumption of maternity. However, the lack of a specific rule for such a situation entails considerable legal uncertainty.
\end{abstract}

Keywords: Assessment of membership; Maternity; Surrogate Mother.

\title{
INTRODUÇÃO
}

Uma indagação de peculiar curiosidade é: de onde nascem as normas jurídicas? Sob uma vertente sociológica, pode-se dizer que elas derivam das fontes materiais do direito. Para Gonçalves (2017), as fontes materiais são os fatores que emergem da sociedade e que levam à elaboração de determinada norma. Diante disso, compreendido o direito como um fenômeno social, é constatável o fato de que conforme a sociedade avança, o direito deve acompanhar tal progresso, adaptando suas normas ao contexto social em que se insere, sob pena de, numa paráfrase de Ferdinand Lassale (2002), tornar-se a legislação um mero aglomerado de folhas de papel.

Atento à necessidade de atualização do direito conforme o avanço tecnológico e cultural da sociedade, o presente trabalho se debruçará sobre uma situação aferível no campo dos 
fatos, mas que ainda não possui um tratamento jurídico específico: a determinação da maternidade nos casos de gestação em útero alheio.

O problema jurídico se origina da seguinte premissa: no Brasil vigora, a presunção de que a maternidade é sempre certa (mater semper certa est), pela qual a maternidade é indicada através de sinais externos inequívocos, tais como a gravidez e o parto (PEREIRA, 2017). No entanto, nos casos de cessão de útero, a parturiente, em tese, não é a mãe. É desse ponto que surge a inquietação jurídica da qual parte o presente trabalho: como é determinada a maternidade na gestação em útero alheio, se no Brasil vigora a presunção de maternidade pelo parto?

Quanto aos objetivos, busca-se traçar um panorama a respeito das técnicas de reprodução assistidas na atualidade, enfatizando o seu tratamento legal. Após, almeja-se explicar a técnica da gestação em útero alheio, realizando a análise de sua legitimidade diante da atual sistemática constitucional brasileira. Por fim, procura-se a compreensão de como se dá a aferição da maternidade na gestação em útero alheio, explicitando as posições em diferentes sentidos.

A metodologia de pesquisa jurídica que se mostra mais adequada para o atingimento dos objetivos acima delineados é a jurídico-sociológica, uma vez que almeja compreender o fenômeno jurídico em um ambiente social mais amplo, pautando-se pela inter-relação entre a ordem jurídica e o meio social em que se insere. Além disso, será adotado o raciocínio dialético, através do procedimento de teses e antíteses a respeito do assunto, visando chegar à síntese que será a resposta para o problema jurídico.

No tocante à justificativa, trata-se de tema ainda pouco discutido, inclusive em sede jurisprudencial e doutrinária, de modo que o presente estudo é inovador e de alta relevância, mormente quando se analisa a insegurança jurídica que pode ser criada em torno da controvérsia a respeito da (in) determinação da maternidade.

Quanto à estrutura do presente artigo, os tópicos seguiram a ordem dos objetivos, como forma de melhorar a compreensão do conteúdo. Em virtude disso, o primeiro tópico tratará do novo conceito de família, trazendo também as transformações pelas quais a estrutura da noção de família passou após promulgação da nova Constituição, traçando uma conexão com a revolução implementada através das técnicas de reprodução artificial. Em seguida, no seguinte tópico, efetua-se um estudo a respeito das técnicas de reprodução artificial em espécie, demonstrando qual o tratamento jurídico conferido pelo ordenamento jurídico. Por fim, o terceiro tópico, se dedicará ao aprofundamento a respeito das correntes existentes a respeito da forma de determinação da gestação em útero alheio no ordenamento jurídico brasileiro. 


\section{A NOVA FEIÇÃo DO DIREITO DE FAMÍLIA E A GESTAÇÃO EM ÚTERO ALHEIO}

O direito de família ocupa um lugar destaque no ordenamento jurídico vigente, tendo em vista que a Constituição da República Federativa do Brasil de 1988 promoveu uma ruptura com o paradigma até então vigente, determinando a conformação da legislação familiarista aos seus novos preceitos. Nesse contexto, os princípios que regiam o direito de família sob à égide do Código Civil de 1916 se mostraram, muitas vezes, incompatíveis com a nova Constituição.

A família, aos moldes do Código Beviláqua (CC/1916), alicerçava-se sobre elementos que se distinguem de sua feição atual. Em primeiro lugar, havia uma supervalorização do casamento, o qual, durante muito tempo, foi a única forma legalizada de constituição familiar, o que fazia com que outros núcleos familiares não desfrutassem da proteção do direito. Além disso, tratava-se de um núcleo hierarquizado, porquanto a figura patriarcal se sobrepunha, em nível de autoridade, aos demais componentes.

Outro princípio que informava a família do século XX era o da heteroparentalidade, uma vez que a instituição familiar somente era reconhecida à união entre homem e mulher, não conferindo legitimidade às uniões homoafetivas. Noutro giro, a família era visualizada como unidade de produção e reprodução, haja vista que havia distinção entre os filhos havidos fora do casamento com aqueles concebidos na constância da relação matrimonial. Por fim, segundo Farias e Roselvald (2016), os laços de filiação eram preponderantemente biológicos, considerando-se familiar aqueles que compartilhassem semelhanças genéticas.

Todavia, com a promulgação da Constituição Federal de 1988, novos preceitos estruturais da família foram instituídos. A nova Constituição trouxe como valor principal o supraprincípio da dignidade, preocupando-se com a personalidade humana em todos os seus aspectos. Tanto é assim, que, conforme Lenza (2016), foi a primeira a trazer um capítulo sobre direitos e garantias fundamentais antes do tratamento acerca da organização do Estado.

Nesse contexto de valorização da pessoa humana, os efeitos sobre o direito de família foram de elevada incidência:

Ora, com a Lex Fundamentallis de 1988 determinando uma nova navegação aos juristas, observando que a bússola norteadora das viagens jurídicas tem de ser a dignidade da pessoa humana (art. $1^{\circ}$, III), a solidariedade social e a erradicação da pobreza (art. $3^{\circ}$ ) e a igualdade substancial (arts. $3^{\circ}$ e $5^{\circ}$ ), o Direito das Famílias ganhou novos ares, possibilitando viagens em mares menos revoltos, agora em "céu de brigadeiro". A família do novo milênio, ancorada na segurança constitucional, é igualitária, democrática e plural (não mais necessariamente casamentária), protegido todo e qualquer modelo de 
vivência afetiva e compreendida como estrutura socioafetiva, forjada em laços de solidariedade (FARIAS; ROSENVALD, 2016, p. 41/42).

Sendo assim, altera-se o centro principiológico da família, adaptando-a à nova feição democratizada trazida pela Constituição Federal de 1988. Nesse contexto, ocorre a pluralização dos núcleos familiares, reconhecendo-se outras formas de constituição e retirando do casamento o protagonismo exacerbado conferido pela legislação anterior. Além disso, o fator biológico deixou de ser o único critério para aferição da filiação, reconhecendo-se a proeminência dos laços socioafetivos. Inaugura-se, também, segundo Dias (2016), a isonomia substancial no âmbito familiar, conferindo-se tratamento igualitário aos seus componentes, sem deixar de levar em conta as próprias vulnerabilidades.

Sob essa perspectiva, vários dispositivos da legislação infraconstitucional foram considerados incompatíveis com a Constituição de 1988, inclusive alguns artigos do Código Civil de 2002, embora promulgado já durante a vigência da nova carta política. Nesse sentido, explica Madaleno (2018) que, a partir da promulgação da nova Constituição, novos princípios promoveram a releitura do direito de família que, durante muito tempo, foi engessado e hierarquizado. Com esse panorama, muitos dos dispositivos presentes na legislação infraconstitucional ordinária são tidos como inconstitucionais, posto que ainda estabelecem uma inadmissível relação de privilégio e discriminação, a exemplo do que acontecia entre o casamento e a união estável. O autor cita ainda, o julgamento realizado pelo Supremo Tribunal Federal, na repercussão geral dos REs 878.694 e 646.721, por meio do qual se declarou inconstitucional o artigo 1.790 do Código Civil, justamente porque fazia diferenciações, a título sucessório entre cônjuges e companheiros.

No entanto, apesar das elevadas mudanças no âmbito do direito familiar, almejando a conformação do direito à nova realidade social, muitas ainda são as situações que carecem de regulamentação ou atualização por parte do legislador. Segundo Júnior e Batista (2017), os avanços da tecnologia e da ciência fizeram surgir novas realidades ainda não legisladas, como o que ocorre, por exemplo, com a gestação em útero alheio.

É nesse contexto de ausência de norma regulamentadora e de considerável insegurança jurídica, que se insere a temática da aferição de filiação no caso de gestação por substituição, através de técnicas de reprodução assistida. Em verdade, conforme Nader (2016), ocorre uma incerteza no âmbito do sistema de aferição de filiação inaugurado pelo Código Civil de 2002 e a sua aplicação quando da realização de procedimento de cessão de útero.

Conforme Farias e Rosenvald (2016, p. 57), a gestação em útero alheio, também conhecida por gestação por outrem, ou ainda surrogate mother, é a técnica utilizada pela 
medicina que busca "permitir que uma paciente, biologicamente impossibilitada de gestar ou de levar a gravidez até o final, possa ter um filho - resultante de fecundação com o seu óvulo gestado em útero de terceira pessoa". Trata-se, portanto, de uma opção às pessoas que não podem levar a gestação a termo de não se verem impossibilitadas de procriarem.

Apesar de o Conselho Federal de Medicina permitir a utilização da técnica - conforme se observa do teor da resolução n 2.168/2017-CFM -, o fato é que inexiste legislação a respeito, de modo que muita insegurança jurídica é gerada, mormente a respeito da validade e eficácia do contrato de cessão de útero e da determinação da filiação em caso de conflito.

Um dos pontos que mais causam celeuma é que, conforme explica Venosa (2017), o ordenamento jurídico brasileiro consagra a presunção de maternidade em razão do parto (mater semper certa est), porquanto presume-se mãe aquela que deu à luz. Entretanto, a possibilidade de gestação por substituição coloca em xeque tal presunção, uma vez que pautada pela cessão de útero.

Inquire-se, portanto, qual o critério de aferição de maternidade se mostra mais adequado aos procedimentos de gestação por substituição, levando-se em conta que inexiste legislação a respeito e que o tema se reveste de extrema importância, porquanto diretamente relacionado ao princípio da dignidade da pessoa humana, tanto dos pais, quanto da criança gestada.

Para melhor compreensão do objeto de estudo e sistematização do presente artigo, os próximos tópicos cuidarão da necessária análise dos procedimentos de reprodução assistida, como foco na gestação por substituição, e dos critérios para aferição da filiação nos casos de utilização de tais técnicas, buscando identificar qual método seria adequado para a resolução de eventual impasse jurídico.

\section{DO TRATAMENTO JURÍDICO ÀS TÉCNICAS DE REPRODUÇÃO ASSISTIDA}

O direito fundamental à procriação, ou direitos reprodutivos, são reconhecidos tanto no âmbito internacional, quanto no ordenamento jurídico brasileiro. Em verdade, conforme Gonçalves (2017), a Constituição Federal consagrou o princípio do livre planejamento familiar, outorgando ao casal a prerrogativa de escolher se terão ou não filhos, bem como a quantidade e forma de concepção.

Por outro lado, segundo Farinati, Rigoni e Müller (2006), a questão da infertilidade é uma preocupação recorrente da medicina que, há tempos, vem buscando soluções para este problema que, segundo dados da Organização Mundial da Saúde, acomete entre 8\% e 15\% dos casais no mundo. O Conselho Federal de Medicina (2017), inclusive, considera a 
infertilidade humana um problema de saúde, com implicações médicas e psicológicas e reitera a legitimidade do anseio em superá-la.

Diante dessa conjuntura, a infertilidade pode consistir em considerável óbice à plena realização humana. Por tal fato, essa emblemática questão já era tratada, desde os tempos antigos, em mitos e analisada sob o prisma de diversas religiões. A título de exemplo nesse sentido, Moura, Souza e Scheffer (2009, p. 29):

Na Bíblia, também se encontra uma riqueza de relatos sobre o nascimento de homens e mulheres inférteis, infertilidades que foram milagrosamente curadas por Deus, e de mulheres que engravidaram extemporaneamente. Deus, atendendo aos seus desejos, transformou-as de estéreis em mães de filhos, conforme diz o Salmo 113:9 - "Faz que a mulher estéril viva em família e seja alegre mãe de filhos". O exemplo mais conhecido é o de Sara, que engravidou aos 90 anos.

A procriação é vista, do ponto de vista bíblico, como um fator de valorização da personalidade. Em verdade, no contexto das sagradas escrituras "a importância e o valor da mulher no quadro da família estão localizados principalmente na sua maternidade", sendo que, do mesmo modo, "o pai é valorizado pelo número de filhos que tem" (MOURA; SOUZA; SCHEFFER, 2009, p. 30).

A ciência, por sua vez, assim como a religião, tratou a questão da procriação como um tema de destaque. Nessa seara, acerca do histórico da evolução da ciência médica quanto às técnicas de reprodução assistida, o primeiro registro que se tem da utilização de tal procedimento data do ano de 1332, ocasião em que árabes aplicaram inseminação artificial em equinos. Todavia, conforme Moura, Souza e Scheffer (2009), do ponto de vista científico, temse que a primeira inseminação artificial foi realizada em 1779, pelo cientista italiano Lázaro Spalanzani, o qual aplicou o sêmen de um cachorro numa cadela no cio, resultando no nascimento de três filhotes.

Em seres humanos, segundo Scarparo (1991), a primeira utilização dessa técnica remonta ao ano de 1494, na ocasião em que a rainha Joana de Portugal submeteu-se, infrutiferamente, à tentativa de inseminação. No entanto, somente por volta do ano de 1785 , ocorreu a primeira inseminação artificial em seres humanos em que se obteve sucesso.

No Brasil, o marco do desenvolvimento das técnicas de reprodução assistida foi o nascimento de Anna Paula Caldeira, o primeiro bebê de proveta brasileiro, em janeiro de 1984 (MOURA; SOUZA; SCHEFFER, 2009). 
Com as técnicas de reprodução assistida (TRA'S) se tornando realidade no Brasil, o Código Civil de 2002, embora timidamente, trouxe algumas regras referentes aos critérios de aferição de paternidade nesses procedimentos. Contudo, é necessário advertir que:

O Código de 2002 não autoriza nem regulamenta a reprodução assistida, mas apenas constata lacunosamente a existência da problemática e procura dar solução ao aspecto da paternidade. Toda essa matéria, que é cada vez mais ampla e complexa, deve ser regulada por lei específica, por um estatuto ou microssistema. Com esses dispositivos na lei passamos a ter, na realidade, mais dúvidas do que soluções, porque a problemática ficou absolutamente capenga, sem a ordenação devida, não só quanto às possibilidades de o casal optar pela fertilização assistida, como pelas consequências dessa filiação no direito hereditário. É urgente que tenhamos toda essa matéria regulada por diploma legal específico. Relegar temas tão importantes aos tribunais acarreta desnecessária instabilidade social (VENOSA, 2017, p. 248).

A regulamentação da matéria, entretanto, ficou a cargo do Conselho Federal de Medicina que edita Resoluções sobre a temática, a exemplo da Resolução CFM no 2.168/2017. Entretanto, antes de adentrar ao estudo do tratamento jurídico das técnicas de reprodução humana assistida, faz-se necessário tecer algumas noções conceituais.

Sob o prisma científico, considera-se reprodução assistida "o conjunto de técnicas, utilizadas por médicos especializados, que tem por finalidade facilitar ou viabilizar a procriação por homens e mulheres estéreis ou inférteis" (SOUZA, 2010, p. 349). Por outro lado, conforme a referida autora, é equivocado pensar que tais técnicas se limitam aos casos de inseminação artificial (IIU) ou fertilização in vitro (FIV). Em verdade, a reprodução assistida não é necessariamente dissociada do sexo, podendo consistir na ministração de medicamentos destinados a viabilizar a fecundação.

$\mathrm{Na}$ falta de legislação regulamentadora sobre o procedimento da reprodução assistida, o Conselho Federal de Medicina, atento à importância de tais técnicas, regulamenta a matéria através de atos administrativos. Nesse contexto, de acordo com o artigo 3ํㅡ, da Resolução no 2.121/2015 do Conselho Federal de Medicina (revisada pela Resolução CFM no 2.168/2017), as principais técnicas de reprodução assistida são: a) Inseminação Artificial; b) Fertilização in vitro; c) Injeção Intracitoplasmática de Espermatozóide; d) Transferência de embriões, gametas ou zigotos.

A inseminação artificial é um procedimento relativamente simples e consiste no manuseio e depósito do sêmen no útero da mulher. Por sua vez, a fertilização in vitro é uma técnica em que os materiais genéticos são mantidos em laboratório, até a formação de préembriões. Após, os pré-embriões são depositados no útero, o que aumenta a taxa de sucesso. 
Por outro lado, na Injeção Intracitoplasmática de Espermatozóide (ICSI) os espermatozoides são injetados no óvulo de maneira direta, diferentemente da inseminação artificial, na qual o sêmen é somente depositado no útero. Por fim, a Transferência de Embriões, Gametas ou Zigotos "procura aumentar o sucesso da nidação, a fecundação poderá ocorrer fora do corpo da mulher ou nas trompas, a depender se a transferência é de gametas ou zigotos" (FREIRE JR; BATISTA, 2017, p. 05/06).

Além das distinções conceituais, Souza (2010) classifica as técnicas de reprodução assistidas em intracorpóreas ou extracorpóreas. De acordo com a referida autora, intracorpóreas são as que se utilizam de métodos de inserção do gameta masculino no sistema genital feminino, ocorrendo a fecundação no interior do corpo da mulher. Por outro lado, nas técnicas extracorpóreas ocorre a manipulação externa do óvulo e do espermatozoide, realizando-se a fecundação fora do corpo da mulher, através de tubo de ensaio ou mídia de cultivo. Após, ocorre a transferência do óvulo fecundado para o útero materno. É o que ocorre, por exemplo, com fertilização in vitro.

Sob outro enfoque, a classificação mencionada pelo Código Civil e que, portanto, mais interessa ao presente artigo, é aquela que divide as técnicas de reprodução assistida em homólogas e heterólogas. De acordo com Madaleno (2018), na fertilização homóloga o material genético é o do próprio casal, isto é, utiliza-se o sêmen do marido ou companheiro e o óvulo da mulher. Por outro lado, na fertilização heteróloga recorre-se ao sêmen ou óvulo de terceiro.

No tocante à aferição de paternidade nesses casos, é consagrada pelo ordenamento jurídico brasileiro, a presunção de paternidade pelo casamento (pater is est quem nuptiae demonstrant), pela qual presumem-se ser do marido os filhos concebidos na constância do casamento. Trata-se de presunção antiquíssima que remonta ao direito romano (GONÇALVES, 2017).

Fundado em tal presunção, estabelece o art. 1.597 do Código Civil que se presumem concebidos na constância do casamento os filhos:

I - nascidos cento e oitenta dias, pelo menos, depois de estabelecida a convivência conjugal; II - nascidos nos trezentos dias subsequentes à dissolução da sociedade conjugal, por morte, separação judicial, nulidade e anulação do casamento; III - havidos por fecundação artificial homóloga, mesmo que falecido o marido; IV - havidos, a qualquer tempo, quando se tratar de embriões excedentários, decorrentes de concepção artificial homóloga; V - havidos por inseminação artificial heteróloga, desde que tenha prévia autorização do marido. (BRASIL, 2002, online, grifos acrescentados). 
No caso da fertilização homóloga, portanto, não há problemas em se definir a paternidade, tendo em vista que o material genético é do próprio casal. Nesse contexto, a lei civil previu a incidência de presunção de paternidade nesse tipo de fertilização, ainda que o marido já tenha falecido, conforme o teor do art. 1.597, inciso III, do Código Civil (BRASIL, 2002). Segundo Farias e Rosenvald (2016), no caso de fertilização heteróloga, havendo consenso e consentimento do marido, incide também a presunção de paternidade.

Acerca da presunção de paternidade previstas nos dois primeiros incisos (I - nascidos cento e oitenta dias, pelo menos, depois de estabelecida a convivência conjugal; II - nascidos nos trezentos dias subsequentes à dissolução da sociedade conjugal, por morte, separação judicial, nulidade e anulação do casamento), para Madaleno (2018), com os avanços da tecnologia da ciência genética, com o que se pode estabelecer com alto grau de certeza a filiação, a presunção pater is est pouco tem de relevante quando contestada por um método mais eficaz de aferição de paternidade como é o DNA, ressalvadas, por óbvio, os casos de filiação socioafetiva.

Percebe-se, entretanto, que as discussões a respeito das regras para aferição de filiação nos casos apresentados, circunda-se em torno da definição da paternidade e não da maternidade. Isso se explica em razão do fato de que as hipóteses até então citadas de reprodução assistida se realizam no corpo da mulher que detém o animus procriacional, isto é, a vontade de ter filho. Nesse caso, para Gonçalves (2017), incide a presunção mater sempre certa est - a mãe é sempre certa - uma vez que indicada pelo parto.

Situação diametralmente diferente é o que ocorre com os casos de gestação em útero alheio, em que existe figura de cessionária de útero. Nesse contexto, considerando-se as peculiaridades da gestação por substituição, o próximo tópico tratará da permissibilidade do contrato de cessão de útero, bem como dos critérios de aferição de maternidade nesses casos.

\section{A GESTAÇÃo POR SUBStituiçÃo E A PRESUnÇÃo de MATERNIDAde PELA GRAVIDEZ}

A indeterminação jurídica acerca da maternidade nos casos de gestação em útero alheio pode levar a situações de grave comprometimento dos direitos da personalidade, tanto da criança quanto dos pais envolvidos. Ao contrário do que possa parecer, conflitos de maternidade já ocorreram ao redor do mundo, ocasionando impasses jurídicos de dificílima solução.

Como exemplo dessas situações, Sandel (2015), no livro Justiça: O que é fazer a coisa certa, conta interessante situação envolvendo a temática da gestação em útero alheio, ou, no 
caso, o contrato de barriga de aluguel. Narra o autor que, no ano de 1985, os norte-americanos William e Elizabeth Stern, da cidade de Tenafly, New Jersey, recorreram a um centro de tratamento para infertilidade que intermediava contratos de barriga de aluguel. Elizabeth sofria de esclerose múltipla e, por isso, não poderia levar uma gravidez a termo sem risco à própria saúde. Foi então que Mary Beth Whitehead se disponibilizou para o procedimento e assinou um contrato com Willian Stern, acordando que se submeteria à inseminação artificial com o material genético deste, recebendo em troca o valor de 10 mil dólares

Segundo Sandel (2015), depois de diversas tentativas de inseminação, Mary engravidou e, no ano de 1986, nasceu uma menina. Após o nascimento, entretanto, a parturiente informou ao casal Stern que não iria entregar a criança e partiu com o bebê para a Flórida. Diante do impasse, os Sterns acionaram o poder judiciário. O juiz Harvey Sorkow, encarregado do julgamento do caso, concluiu que o contrato de barriga de aluguel era válido e que, portanto, deveria ser cumprido. Além disso, o magistrado argumentou que o consentimento dado por Mary Beth era perfeitamente válido, posto que não havia provas de que ela houvesse sido de alguma forma influenciada. Noutro giro, o juiz negou a argumentação de que a barriga de aluguel, naquele caso, configuraria a venda de um bebê. Em primeiro lugar, porque o filho era do Sr. Stern, uma vez que concebido com seu material genético. Além disso, o magistrado também rejeitou a alegação de que o contrato se fundava em exploração da mulher. Sorkow comparou o contrato de barriga de aluguel com a doação de esperma, posto que se aos homens é dado ceder o seu material biológico, à mulher também deve ser conferida a faculdade de ceder, ainda que onerosamente, o seu sistema reprodutivo.

Acrescenta Sandel (2015) que foi expedida a ordem judicial e a criança foi encontrada pela polícia da Flórida e entregue ao casal Stern. Inconformada, Mary Beth recorreu à Suprema Corte de Nova Jersey, a qual, por unanimidade, anulou a decisão do Juiz Sorkow e declarou nulo o contrato de gravidez de aluguel. Segundo a Suprema Corte de Nova Jersey, o consentimento dado por Mary Beth, antes do nascimento da criança, não foi totalmente voluntário e que o contrato, naqueles termos, constituía um comércio de bebê. Diante disso, reconheceu a paternidade do Sr. Stern e a maternidade da Sr. Mary Beth. Por outro lado, tendo em vista o melhor interesse da criança, concedeu a guarda à Willian Stern, porquanto possuía melhores condições de cria-la. Oportunizou, no entanto, a Mary Beth o direito de visitas regulares.

O caso emblemático estadunidense ficou conhecido como Baby $M$ e serve para ilustrar a temática a respeito dos impasses jurídicos que circundam a determinação da filiação nos casos de gestação em útero alheio. Segundo Silva (2009), o Brasil, assim como em outros países, não 
possui uma legislação específica sobre o procedimento, o que gera considerável insegurança jurídica.

A gestação por substituição, também chamada de gestação em útero alheio, ou, impropriamente, de barriga de aluguel, é o procedimento em que se recorre à cessão temporária do útero de uma terceira pessoa, quando a mulher detentora do animus procriacional não tem condições biológicas para o progresso normal da gravidez. Nas palavras de Silva (2003, p. 32) "esta técnica consiste em apelar a uma terceira pessoa para assegurar a gestação quando o estado de útero materno não permite o desenvolvimento normal do zigoto ou quando a gravidez apresenta um risco para a mãe".

Conforme Teixeira (2016), nos tempos antigos, a infertilidade da mulher era solucionada pelo adultério consentido, isto é, a mulher recorria às escravas para dar filhos ao marido. $\mathrm{Na}$ Bíblia, inclusive, há passagens que relatam esse tipo de procedimento:

O Velho Testamento já fazia referência às mães por substituição, no livro do (30-3), narrando o drama de Raquel, em razão de sua infertilidade, descrevendo com minúcias a do problema, por meio da colaboração de outra mulher para o nascimento do filho de Jacó: "Raquel disse a Jacó: 'Aqui tens a minha serva, vai ter com ela. Que dê à luz sobre os meus joelhos; assim com ela eu também terei filhos" (FARIAS; ROSENVALD, 2016, p. 572).

Diante disso é possível afirmar que a preocupação em se encontrar opções à infertilidade data de muito tempo. Com os avanços científicos, principalmente através das técnicas de reprodução assistida, a gestação em útero alheio pode ocorrer sem a prática do adultério consentido.

Ainda sobre as noções conceituais sobre maternidade por substituição, explica Abreu (apud FARIAS; ROSENVALD, 2016, p. 572) que na gestação em útero alheio ou gestação por substituição "a maternidade é dividida ou dissociada: a mãe genética, por impossibilidade física recorre à outra mulher, mãe gestacional, para que esta leve a termo a gravidez impossível daquela". Nesse contexto, ocorre a renúncia da mãe que gera, chamada de mãe hospedeira ou gestatriz, em favor da mulher que cedeu o material biológico (chamada de mãe biológica).

De acordo com Chagas e Nogueira (2013), no tocante à possibilidade jurídica do contrato de cessão de útero, alguns países, como a Alemanha, Espanha, França, Itália e Portugal, proíbem expressamente a gestação por substituição. Por outro lado, na Inglaterra e na Índia a prática é admitida, inclusive de maneira remunerada no país asiático. Quanto à prática de gestação por substituição na Índia, explica Silva (2011, p. 52/53): 
Mulheres indianas disponibilizam seu útero como quem se candidata a um emprego qualquer. Aliás, para elas, gestar filho de outrem é algo tão natural quanto exercer a atividade de bancária, empregada doméstica ou qualquer outra, pelo que, depois do parto, entregam imediatamente a criança a encomendante. Desde 2002, essa prática é legal no país, o que leva casais do mundo todo a procurar essas mulheres, em razão do baixo custo que representam. Enquanto uma americana gasta com o procedimento na Califórnia cerca de 200 mil dólares, e ainda precisa pagar mais 80 mil dólares para alugar uma barriga, o gasto total é de apenas 20 mil dólares na Índia. Desse valor, a mãe de aluguel recebe cerca de 4.500 dólares.

Por outro lado, no ordenamento jurídico brasileiro, Nader (2016) afirma que não há nenhuma regulamentação legal para a gestação por substituição na legislação pátria, devendo sua permissibilidade ser analisada pela jurisprudência e pela doutrina. Em verdade, a doutrina diverge sobre o assunto, podendo ser divididos em três grupos: a) aqueles que entendem pela vedação à prática, ainda que a título gratuito; b) aqueles que admitem a possibilidade de gestação em útero alheio, ainda que de forma remunerada, e; c) os que entendem pela possibilidade do procedimento, desde que não se trate de cessão onerosa.

Capitaneando o primeiro grupo, Gama (2003) leciona que, levando-se em conta o estágio atual dos valores culturais no Brasil, bem como a influência dos princípios religiosos e morais que informam a maior parte da sociedade, não há como se permitir a prática da gestação por substituição, ainda que se trate de cessão gratuita. Por outro lado, adverte o autor que, ocorrendo a prática, ainda que de forma ilícita, devem ser resguardados todos os direitos da criança, principalmente o de integrar uma família que lhe dê amparo, sustento, educação e afeto, de modo a propiciar seu desenvolvimento integral.

Em posição diametralmente oposta, encontram-se aqueles que entendem pela admissibilidade da gestação por substituição ainda que de maneira remunerada, popularmente conhecida por "barriga de aluguel". Nesse sentido, sustenta Teixeira (2016, p. 141):

Deve-se ter em mente que gerar a criança para alguém realmente deveria envolver exclusivamente um fim altruístico, mas as desigualdades sociais e econômicas influenciam nas escolhas da sociedade, assim, essa gestação pode não caracterizar um comércio de bebês, mas apenas a forma de unir o sonho de alguém sem a possibilidade de gestar com a necessidade de outras pessoas. Saliente-se também que não se trata de venda de uma criança ou dos direitos da mãe sobre um filho, salvo se a mãe parturiente também contribuiu com o material genético necessário, pois, se não foi assim que ocorreu, a verdadeira mãe é a pessoa que teve o ânimo materno desde o início e forneceu o óvulo para ser fecundado e inseminado na mãe de aluguel.

Conforme demonstra autora, a cessão temporária de útero de maneira remunerada (barriga de aluguel) não deve ser enxergada somente com pontos negativos. Em verdade, se 
trataria de uma troca de benefícios mútuos entre pessoas capazes, proporcionando bem-estar a ambas. À mãe biológica, detentora da vontade procriacional, que teria seu filho e à gestatriz que poderia melhorar suas condições financeiras com o procedimento.

Sem embargo das orientações em sentido contrário, a possibilidade cessão onerosa de útero esbarra em expressa proibição constitucional. Com efeito, o art. 199 da Constituição Federal proíbe a comercialização de órgão ou tecido humano. No entanto, para Almeida (2000) a cessão temporária de útero não é um comércio ilegal do corpo humano, sob a argumentação de que se trata, em verdade, de venda da prestação de serviço da gestação e não de venda de bebês. Além disso, a referida autora esclarece que não se pode comparar a utilização do útero com a remoção de um órgão humano, posto que a simples cessão do útero de uma mulher saudável não poderia ocasionar problemas para o futuro, diferentemente do que ocorreria com a retirada de um rim.

Não obstantes tais argumentos, a cessão de útero, nesses termos, poderia configurar uma exploração da figura feminina, principalmente nas condições citadas, principalmente em países com baixos indicadores socioeconômicos como o Brasil. Admitir a prática da "barriga de aluguel", nesse contexto, poderia ocasionar a abertura de um verdadeiro comércio de exploração em que, por baixos preços, mulheres de baixa renda se submeteriam a tais procedimentos.

Diante desse panorama, prevalece a orientação acerca da permissibilidade da utilização da gestação por substituição, desde que desvinculado do aspecto remuneratório. Em outras palavras, é válida a cessão de útero realizada graciosamente.

Malgrado haja posições em sentido contrário e inexiste legislação específica sobre o tema, o Conselho Federal de Medicina, através da Resolução CFM no 2.168/2017, regulamentou a gestação por substituição, permitindo o procedimento desde que obedecidos alguns requisitos.

De acordo com a Resolução no 2.168/2017, permite-se a gestação de substituição, "desde que exista um problema médico que impeça ou contraindique a gestação na doadora genética, em união homoafetiva ou pessoa solteira". Diante disso, observa-se que deve haver um motivo de saúde ou impossibilidade biológico que impeça a gestação, não bastando para tanto justificativas de ordem estética ou profissional.

Outro ponto que merece destaque, como ensina Dias (2016), é que no caso de casal formado por duas mulheres, quando uma gesta o óvulo da companheira que foi fecundado em laboratório, não ocorre, propriamente, a gestação por substituição, mas se trata de caso de dupla maternidade. 
A Resolução CFM no 2.168/2017 ainda prevê diversas outras regras a respeito da cessão de útero. Em primeiro lugar, o ato normativo proíbe expressamente a realização da gestação por substituição com caráter lucrativo ou comercial. Em verdade, conforme Dias (2016), a proibição torna imprópria a denominação "barriga de aluguel", uma vez que é vedada a remuneração pela gestação.

Noutro vértice, é necessário observar que

Malgrado a gratuidade do ato, a mãe-gestacional fará jus a assistência médica e psicológica, custeada pelos interessados na gestação, a partir do referencial da boa-fé objetiva ( $\mathrm{CC}$, art. 422). Isso porque, em se tratando de negócio jurídico celebrado no interesse de quem pretende exercer a filiação, mostra-se absolutamente razoável impor eventual responsabilidade civil para arcar com as despesas decorrentes de tratamentos médicos e psicológicos decorrentes da gestação em relação à mãe-hospedeira (FARIAS; ROSENVALD, 2016, p. 573).

Diante disso, o que se proíbe é a remuneração pela gestação em si, porém não há como deixar de ressarcir à gestatriz os gastos que terá com o procedimento, por questões de boa-fé e responsabilidade civil.

Convém destacar, ainda de acordo com a referida resolução, que é necessário que a gestatriz tenha vínculo de parentesco com um dos parceiros interessados, no máximo até o quarto grau. Nos demais casos, o procedimento fica sujeito a autorização pelo conselho regional de medicina respectivo.

Nesse contexto, a Resolução do Conselho Federal de Medicina (2017, online) ainda exige uma série de formalidades para que se realize a gestação por substituição. Em primeiro lugar, exige-se um termo de consentimento, o qual deverá ser "livre e esclarecido assinado pelos pacientes e pela cedente temporária do útero, contemplando aspectos biopsicossociais e riscos envolvidos no ciclo gravídico-puerperal, bem como aspectos legais da filiação". Segundo Pereira e Cardoso (2018), o referido documento termo possui elevada importância, principalmente para fins de comprovação que existe uma dissociação entre a vontade de procriar e a gravidez, aspecto a ser levado em conta no momento de aferição da filiação.

Além do termo de consentimento, é necessário ainda um relatório médico que ateste a adequação clínica e emocional dos envolvidos para o procedimento da gestação por substituição. Noutro giro, são imprescindíveis para a realização do procedimento:

Termo de Compromisso entre o (s) paciente (s) e a cedente temporária do útero (que receberá o embrião em seu útero), estabelecendo claramente a questão da filiação da criança; Compromisso, por parte do (s) paciente (s) contratante (s) de serviços de RA, de tratamento e acompanhamento médico, inclusive por 
equipes multidisciplinares, se necessário, à mãe que cederá temporariamente o útero, até o puerpério; Compromisso do registro civil da criança pelos pacientes (pai, mãe ou pais genéticos), devendo esta documentação ser providenciada durante a gravidez; Aprovação do cônjuge ou companheiro, apresentada por escrito, se a cedente temporária do útero for casada ou viver em união estável (CFM, 2017, online).

Dentre tais requisitos contidos, que se destinam a atribuir caráter de legitimidade à gestação por substituição, cabe destaque ao termo de compromisso entre os pacientes e a cedente temporária de útero no que toca aos aspectos filiatórios. Com efeito, conforme propugna Nader (2016), cuida-se do ponto nevrálgico de toda a temática, posto que sempre vigorou no Brasil a presunção de maternidade pelo parto. Desse modo, enorme é a discussão que permeia a filiação no caso de gestação em útero alheio, cujos principais aspectos serão demonstrados nos termos seguintes.

Segundo Gonçalves (2017), a filiação é a relação de parentesco, estabelecida em primeiro grau e linha reta, ligando uma pessoa àquelas que a geraram (consanguinidade) ou que a receberam como se tivessem gerado (afetividade). Em outras palavras, cuida-se da relação de parentesco que se estabelece entre pais e filhos.

Nesse sentido, vale destacar que, conforme Gonçalves (2017), a filiação pode ser entendida em dois sentidos. Num sentido estrito, é a relação jurídica estabelecida entre os pais e os filhos, de modo que filiação propriamente dita é aquela visualizada pela ótica do filho em relação aos pais. Por outro lado, também poderá tomar o sentido de paternidade/maternidade quando analisada pela ótica dos genitores em relação aos filhos.

Nesse contexto, com aporte no conceito de filiação e com as noções já trazidas a respeito das técnicas de reprodução assistida, principalmente a gestação em útero alheio, inquire-se: como deve ser aferida a maternidade nos casos de gestação por substituição?

Em primeiro lugar, importa esclarecer que a definição da maternidade é, desde muito tempo, informada pela presunção mater semper certa est (a mãe é sempre certa). Os autores Campos e Takeyama (2015) informam que se trata de uma presunção jurídica que remonta ao Direito Romano e quer dizer, em termos simples, que a mãe será aquela que apresentar sinais inequívocos de maternidade, como são a gestação e o parto.

Na maioria das situações, portanto, a maternidade não é uma questão de difícil aferição, porquanto a parturiente será considerada a mãe. No entanto, a mesma aferição demanda estudos mais aprofundados quando se trata de gestação por substituição, uma vez que a parturiente, nesse caso, não é aquela que detém o animus procriacional. 
Como já vislumbrado em linhas anteriores, a gestação por substituição é uma relação complexa, uma vez que envolve pessoa alheia ao projeto procriatório, a qual será responsável, justamente, pela gestação. Nesse sentido, segundo Pereira e Cardoso (2018), no caso da gestação em útero alheio compõem a relação: "um casal que deseja uma criança (e é impossibilitado de gestar) e uma mulher que cedeu seu útero temporariamente" para a gestação da criança.

Inicialmente, cumpre ressaltar que não são raros os casos em que ocorre conflito entre a gestatriz e o casal detentor do projeto filiatório, principalmente quando a segunda se nega a entregar a criança aos últimos. Em verdade, há registros de situações em que isso ocorreu, como no supracitado caso Baby $M$, em que a cedente de útero se negou a cumprir o contrato e não quis entregar a criança ao casal com quem celebrou termo de compromisso (SANDEL, 2015). Atentando-se à sensibilidade da temática, casos ainda mais delicados podem ocorrer. $A$ título exemplo, conforme Farias e Rosenvald (2016), no ano de 1983, em Michigan nos Estados Unidos, um bebê nasceu com microencefalia e foi rejeitado pela mãe hospedeira e também pelos genitores biológicos.

Posto isso, assevera Welter, citado por Madaleno (2018), que a posição que vem prevalecendo na maioria dos países é que, mesmos nos casos de gestação em útero alheio, a maternidade deve ser definida pelo parto, negando-se validade aos contratos de gestação substituta. Em muitos países, a cessão de útero é considerada, até mesmo, um ilícito penal, tal como ocorre na Espanha. A despeito disso, o autor anota que vem crescendo o número de decisões judiciais que tem conferido a maternidade àquela que detém à vontade procriacional. Diante desse panorama, não há como negar que se trata de um assunto controvertido.

$\mathrm{Na}$ esteira do que leciona Madaleno (2018), no direito comparado, verifica-se que, na Espanha, em virtude da ausência de validade jurídica do contrato de gestação por substituição, a maternidade é outorgada àquela que deu à luz. Ademais, também de acordo com o referido autor, a Alemanha, do mesmo modo, determina a aplicação da presunção de maternidade pelo parto, não se conferindo legitimidade à doação de óvulos ou ao contrato de gestação substituta, consoante se extrai do parágrafo 1.591 do Código Civil Alemão-BGB. No mesmo sentido, Silva (2011, p. 54) explica que:

Na legislação comparada, em caso de conflito de maternidade, tem prevalecido o princípio de que a mãe é a que dá à luz a criança. A maternidade é legalmente estabelecida pelo parto, e não pela transmissão do patrimônio genético. É assim na França, na Suíça e na Espanha. Nos Estados Unidos as decisões dos estados têm apontado que mãe da criança não é a sub-rogada, mas a que tenha fornecido o óvulo, prestigiando nesse caso o vínculo genético. 
Verifica-se, portanto, que a presunção mater semper certa est possui grande aplicação no direito internacional, inclusive prevalecendo sobre o contrato de gestação por substituição em muitos países. É necessário, no entanto, compreender como a questão é abordada no Brasil, país em que, como anteriormente vislumbrado, não há legislação específica sobre o assunto, ficando a regulamentação a cargo do Conselho Federal de Medicina.

De acordo com Pereira e Cardoso (2018, p. 176), a presunção mater semper certa est deve ser relativizada no caso de cessão de útero, em virtude da participação "de uma pessoa alheia aos autores do projeto parental". Para os autores, ocorre em tal caso uma dissociação, isto é, uma separação entre o desejo da maternidade e a gravidez. Por tais razões, a presunção somente deve continuar vigorando em relação à gravidez decorrente de atividade sexual dos parceiros, não se aplicando ao caso de gestação por substituição. É também a proposta de Farias e Rosenvald (2016, p. 575):

Sob o ponto de vista filiatório, não se pode deixar de notar que, apesar da falta de disciplina legal expressa, a gestação em útero alheio implica em relativização da presunção mater semper certa est (a mãe é sempre certa, indicada pelo parto), derrubando, identicamente, a incidência da presunção pater is est (segundo a qual o pai do filho de uma mulher é o seu marido). Em tais hipóteses, a determinação de filiação será submetida a outros critérios, em especial o cumprimento aos requisitos estabelecidos na Resolução do Conselho Federal de Medicina, devendo ser prestigiada a filiação biológica, garantindo-se a quem emprestou material genético o estabelecimento da relação de parentesco.

Afastada, no entanto, a aplicação da presunção de maternidade, fica ainda o questionamento a respeito de qual o critério deve ser utilizado para aferição da maternidade. Silva (2011, p. 58/59) entende que, no caso da gestação em útero alheio

O elemento volitivo assume papel relevante. A vontade procriacional é fonte do vínculo materno-filial, reveladora da vontade de ser mãe, do desejo de constituir um vínculo com a criança concebida com a ajuda de métodos científicos, vontade essa que é declarada pela manifestação de consentimento, corroborando a natureza jurídica do instituto, de modo que ligará os encomendantes à criança.

De acordo com tal raciocínio, a determinação da filiação está no estado anímico, isto é, na vontade de ser mãe/pai. Daí ressalta a importância do termo de consentimento e compromisso que é exigido pela Resolução CFM no 2.168/2017, documentos em que deverá ser claramente determinada a filiação, isto é, a exposição de quem detém a vontade de ser mãe/pai e quem apenas cederá temporariamente o útero para a gestação. 
Com o mesmo entendimento, Dias (2016) leciona que a cessão de útero afasta tanto a aplicação da presunção de maternidade pela gravidez e pelo parto, quanto a presunção de paternidade pelo casamento. Afirma a autora, que pelo fato de a parturiente não transmitir carga biológica ao concepturo, o que se pode afirmar nos casos de gestação por substituição é que a gestatriz é sempre certa, mas não que a mãe é sempre certa.

Entrementes, a atribuição de maternidade àquela que detém a vontade procriacional e o consequente afastamento da presunção de maternidade certa dependem, inexoravelmente, da validade do contrato de gestação por substituição. Isto é, para que surta seus efeitos jurídicos, é necessário que o pacto de cessão de útero atenda aos requisitos previstos na Resolução CFM no 2.168/2017, principalmente no que tange à gratuidade do ato, porquanto a barriga de aluguel é vedada pelo referido ato normativo.

Nesse sentido, Madaleno (2018) argumenta que não há conflitos de maternidade quando a gestação por substituição se fundamenta na solidariedade familiar e afetiva e é realizada sem fins lucrativos. Para o autor, nos casos de gestação em útero alheio - em que se obedece aos requisitos estabelecidos pelo Conselho Federal de Medicina - a filiação deve ser determinada pelo elemento volitivo, ou seja, deve ser atribuída a quem teve a vontade de ter o filho e assumir a responsabilidade por seu nascimento, criação, educação e todos os deveres da maternidade/paternidade.

Noutro vértice, havendo conflito entre a gestatriz e os detentores do projeto parental, deverá ser solucionado com aporte nas peculiaridades do caso concreto e sempre com fundamento no maior interesse da criança. Desse modo, conforme Madaleno (2018), não ganha tanta relevância a verdade biológica - aferível por exames de DNA -, mas um conjunto de fatores que poderão influenciar na formação da personalidade da criança.

Percebe-se, portanto, que Madaleno (2018) apresenta uma solução mais casuística para eventual conflito, demonstrando que há sempre a necessidade de buscar a efetivação dos direitos da criança. Entretanto, nos casos em que a gestação por substituição é realizada de acordo com os preceitos da solidariedade familiar e a título gratuito, a determinação da filiação deve ser feita com fulcro na demonstração da vontade procriacional. É, inclusive, a posição que prevalece no Brasil, embora haja autores, tal como Paulo Nader (2016) que defendem a aplicação da presunção de maternidade certa, mesmo em se tratando de gestação por substituição.

Um outro ponto que merece análise, é aquele que toca às questões do registro civil da recém-nascido havido por gestação em útero alheio. Em verdade, determina a Lei dos Registros Públicos (Lei nº 6.015/73) o registro de nascimento conforme declaração de nascido 
vivo emitido pelo médico que realizou os procedimentos do parto. Conforme Farias e Rosenvald (2016), não haverá problemas se o médico que realizou o parto, for o mesmo que acompanhou o procedimento de gestação por substituição. Em tal caso, o médico deverá inscreve na Declaração de Nascido Vivo o nome da mãe biológica ou social, isto é, da detentora do projeto parental. Entretanto, advertem os autores que

(...) se o médico que realizar o parto não for o mesmo que promoveu a fertilização em útero alheio, vindo a ser declarada a maternidade da mãe hospedeira (no registro de nascido vivo assinado pelo médico), o interessado (a mãe biológica, o pai, o Ministério Público...), ou o próprio Oficial do Registro Civil de ofício, suscitará o procedimento de dúvida (art. 296 c/c os arts. 198 a 204 da Lei no 6.015/73) ao juiz da Vara de Registros Públicos, para que, com o auxílio da prova pericial (DNA) e ouvido o Parquet, seja determinada a inscrição do nome da mãe biológica no registro de nascimento (FARIAS; ROSENVALD, 2016, p. 574).

No mesmo sentido, Dias (2016) ressalta que, nos casos de gestação por substituição, ainda que seja geratriz que receba em seu nome a Declaração de Nascido Vivo, vem sendo assegurado o registro do filho no nome da detentora do projeto parental. De acordo com a autora, há tribunais que expediram resoluções autorizando o referido registo sem a necessidade de demanda judicial. Além disso, há decisões judiciais autorizando que a própria Declaração já seja expedida no nome daquela que irá assumirá a maternidade.

Superados os necessários apontamentos sobre o registro civil, convém destacar que o tema da aferição da maternidade em caso de gestação por substituição demanda urgente regulamentação pelo Poder Legislativo, a fim de conferir segurança jurídica e evitar a proliferação de conflitos de filiação. Como já analisado em linhas anteriores, as técnicas de reprodução assistida e também a gestação em útero alheio são realidades no Brasil, constituindo uma prática utilizada por muitos casais que possuem problemas de infertilidade.

É nesse contexto, que Silva (2011, p. 59) afirma que a falta de lei específica que trace critérios para aferição da maternidade nesses casos acarreta uma excessiva dificuldade de julgamento nos casos de conflito, sendo imprescindível que o Poder Legislativo elabore uma norma que trate dessa temática, enfatizando a "prevalência da presunção de maternidade e paternidade em prol do casal que idealizou o nascimento, sendo dele o filho aos olhos da lei, independentemente da origem do material genético que o concebe, ou do útero em que se torna viável".

Observa-se, com base nisso, que a insegurança jurídica que circunda a problemática faz necessária a rápida atuação do poder legislativo, a fim de conferir legitimidade à gestação por 
substituição, bem como estabelecer os critérios de aferição de maternidade. Com efeito, conforme Farias e Rosenvald (2016, p. 575) aduzem que a discussão chegou à Jornada de Direito Civil, ocasião em que elaborou o Enunciado 129, o qual propõem uma nova redação para o artigo 1.597-A do Código Civil:

Artigo 1.597-A - A maternidade será presumida pela gestação. Parágrafo único - Nos casos de utilização das técnicas de reprodução assistida, a maternidade será estabelecida em favor daquela que forneceu o material genético, ou que, tendo planejado a gestação, valeu-se da técnica de reprodução assistida heteróloga (CJF, 2012, p. 32).

A expressa disposição legal afastaria grande parte das hipóteses de conflitos de maternidade e conferiria maior segurança jurídica ao procedimento da gestação em útero alheio. Desse modo, considerando o teor sensível da matéria e os direitos fundamentais em jogo, não deve demorar muito tempo até que o legislativo trate efetivamente da matéria, sob pena de configurar indiscutível omissão inconstitucional.

No tocante à aferição da maternidade, portanto, prevalece em sede doutrinária o entendimento que deve ser atribuída à detentora do projeto parental. Por outro lado, verifica-se que, até que se edite norma explicitando a regra, a problemática continuará revestida de diversas discussões, principalmente nos casos de conflitos. Desse modo, remonta-se ao início do presente artigo quando se disse que a sociedade caminha mais rápido que o direito. $A$ despeito disso, conforme também já apontado, o direito possui o dever de adaptação ao meio social em que se insere, sob pena de não atingir sua finalidade precípua - a pacificação social.

\section{CONSIDERAÇÕES FINAIS}

Ao abordar um tema que envolve os direitos e garantias fundamentais da pessoa, é preciso ter noção da importância que o ordenamento jurídico-constitucional brasileiro conferiu a tais prerrogativas. A gestação em útero alheio envolve os direitos reprodutivos, de modo que, ao desenvolver um estudo a respeito, promove-se o entendimento acerca de uma parcela dos direitos da personalidade.

A inquietação da qual partiu o presente estudo era ainda mais profunda, visava-se compreender como se deve ser aferida a maternidade nos casos de gestação em útero alheio. Antes, entretanto, realizou-se um estudo sobre a moderna compreensão de família. Inicialmente, pode-se constatar, com base em Madaleno (2018), Dias (2016) e Farias; Rosenvald (2016), que a noção de família patriarcal, hierarquizada, matrimonializada e regida 
por laços biológicos do século XX, cedeu lugar a um novo modelo familiar, pautado na igualdade entre seus membros, no reconhecimento de diversas formas de constituição de família e com tratamento adequado às relações socioafetivas.

Foi também delineado que as técnicas de reprodução assistida passaram a se inserir no cotidiano das famílias brasileiras, de forma a já constituir uma realidade no Brasil há algum tempo. Junto com essas técnicas, pode-se perceber que a gestação em útero alheio também é utilizada, contudo ainda não haja legislação regulamentando sua permissibilidade e outros aspectos juridicamente relevantes de sua existência. Um desses aspectos é a aferição da maternidade nos contratos de cessão de útero.

Num primeiro momento, abordou-se a própria legitimidade dos contratos de cessão de útero, constatando que, desde que sejam gratuitos, eles são aceitáveis, também dentro do princípio de solidariedade social, como apontam Farias e Rosenvald (2016).

Ultrapassada a etapa de aferição de legitimidade do contrato de cessão de útero, passou-se à análise do critério adequado para aferição da maternidade na gestação por substituição. Em primeiro lugar, discorreu-se a respeito da aplicação da presunção de maternidade pelo parto, observando-se que é defendida por Nader (2016) até mesmo nos casos de gestação por substituição.

No entanto, constatou-se, com base nas lições de Farias e Rosenvald (2016), bem como de Madaleno (2018) e Dias (2016), que no caso de gestação em útero alheio há uma relativização da presunção de maternidade, devendo ser adotado outro critério para a aferição da filiação nesse caso.

O critério que mais foi apontado como adequado, com base nos autores supracitados, os quais são também acompanhados por Silva (2011), é a aferição de quem, no âmbito do contrato de cessão de útero, possui o projeto parental, isto é, a vontade de ter filhos. Sendo assim, será mãe aquela que projetou o nascimento e buscou meios para que isso ocorresse, embora tenha se valido de útero alheio.

No entanto, verificou-se que a admissibilidade da gestação em útero alheio passa pela obediência a todos os requisitos previstos na Resolução 2.168/2017 do Conselho Federal de Medicina, principalmente no que tange à documentação exigida e à inexistência de onerosidade do procedimento.

Ademais, pôde-se averiguar que a inexistência de uma norma específica sobre o tema acarreta considerável insegurança jurídica, principalmente no que tange aos casos em que há conflito de maternidade, tal como no emblemático caso Baby $M$, citado por Sandel (2015). Desse modo, a consideração mais precisa extraível do presente estudo é que se demanda com 
urgência uma norma que trate da filiação nos contratos de cessão de útero, sob pena de se pôr em perigo os direitos e garantias fundamentais dos envolvidos.

\section{REFERÊNCIAS}

ALMEIDA. Aline Mignon. Bioética e Biodireito. Rio de Janeiro. Lumen Juris. 2000

ASENSI, Felipe. Reinvenção do Ensino: Sociedade caminha cada vez mais rápido que o direito. ConJur, 2013. Disponível em: https://www.conjur.com.br/2013-nov-10/felipe-asensisociedade-caminha-cada-vez-rapido-direito. Acesso em: 22.04.2019.

BRASIL. Constituição (1988). Constituição da República Federal do Brasil. Brasília, DF: Senado Federal, 1988.

- Lei n. 3.071, de $1^{\circ}$ de janeiro de 1916. Código Civil. Disponível em: http://www.planalto.gov.br/CCIVIL/leis/L3071.htm. Acesso em: 22 de abr. 2019.

. Lei n. 10.406, de 10 de janeiro de 2002. Código Civil. Disponível em: http://www.planalto.gov.br/ccivil_03/leis/2002/l10406.htm. Acesso em: 22 de abr. 2019.

CAMPOS, Renan Andrade; TAKEYAMA, Celina Rizzo. A maternidade na gestação por substituição homóloga. Anais Eletrônico. IX EPCC - Encontro Internacional de Produção Científica UniCesumar. Nov. 2015, n. 9, p. 4-8.

CHAGAS, Márcia Correia; NOGUEIRA, Maria Alice Pinheiro. Maternidade de Sub-rogação e Direitos Fundamentais: o Planejamento Familiar e Gestação em Útero Alheio. Revista da Faculdade de Direito, v. 34, n. 1, p. 333-354, 2013.

CONSELHO DE JUSTIÇA FEDERAL. Jornadas de direito civil I, III, IV e V: enunciados aprovados. Coordenador científico Ministro Ruy Rosado de Aguiar Júnior. - Brasília: Conselho da Justiça Federal, Centro de Estudos Judiciários, 2012.

. Resolução CFM n.o 2168/2017. Disponível em: http://www.portalmedico.org.br/resolucoes/CFM/2017/2017.pdf. Acesso em: 22 abr. 2019.

Resolução CFM n.o 2125/2015. Disponível em:

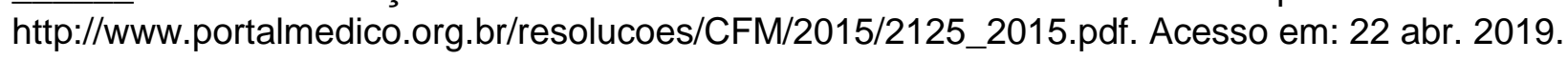

DIAS, Maria Berenice. Direito das famílias - 4aㅗ ed. - São Paulo: Editora Revista dos Tribunais, 2016.

FARIAS, Cristiano Chaves de; ROSENVALD, Nelson. Curso de direito civil: famílias. - 9. ed. rev. e atual - Salvador: Ed JusPodivm, 2016. 
FARINATI, Débora Marcondes; RIGONI, Maisa dos santos; MÜLLER, Marisa Campio. Infertilidade: um novo campo da psicologia da saúde. Estudos de Psicologia, v. 23, n. 4, p. 433-439, 2006.

GAMA, Guilherme Calmon Nogueira. A reprodução assistida heteróloga sob a ótica do novo Código Civil. Revista dos Tribunais, São Paulo, ano 92, v. 817, p. 11-34, nov. 2003.

GONÇALVES, Carlos Roberto. Direito civil brasileiro, volume 6: direito de família. - 14. ed. São Paulo: Saraiva, 2017.

JÚNIOR, Aluer Baptista Freire; BATISTA, Lorrainne Andrade. A Cessão Temporária de Útero: Possibilidade Legal. REMAS-Revista Educação, Meio Ambiente e Saúde, v. 7, n. 4, p. 1-19, 2017.

LASSALE, Ferdinand. O que é uma Constituição; trad. Hiltomar Martins Oliveira. Belo Horizonte: Ed. Líder, 2002.

LENZA, Pedro. Direito constitucional esquematizado. - 20. ed. rev., atual. e ampl. - São Paulo: Saraiva, 2016.

MADALENO, Rolf. Direito de família. - 8. ed., rev., atual. e ampl. - Rio de Janeiro: Forense, 2018

MOURA, Marisa Decat de; SOUZA, Maria do Carmo Borges de; SCHEFFER, Bruno Brum. Reprodução assistida: um pouco de história. Revista da SBPH, v. 12, n. 2, p. 23-42, 2009.

NADER, Paulo. Curso de direito civil, v. 5: direito de família. - Rio de Janeiro: Forense, 2016.

PEREIRA, Caio Mário da Silva. Instituições de direito civil - Vol. v/atual. PEREIRA, Tânia da Silva. - 25. ed. rev., atual. e ampl. - Rio de Janeiro: Forense, 2017.

PEREIRA, Priscila Maria da Silva; CARDOSO, Ana Lucia Brunetta. A cessão temporária de útero: uma análise sobre a (im) possibilidade contratual à luz do direito civil constitucionalizado. Justiça \& Sociedade-Revista do Curso de Direito do IPA, v. 3, n. 1, 2018.

REALE, Miguel. Lições preliminares de direito. - 19a․ ed. - São Paulo: Saraiva, 1991.

SANDEL, Michael. Justiça: o que é fazer a coisa certa. - Rio de Janeiro: Civilização Brasileira, 2015.

SCARPARO, Monica Sartori. Fertilização assistida: questão aberta: aspectos científicos e legais. In: Fertilizaçao assistida: questão aberta: aspectos científicos e legais. 1991.

SILVA, Flavia Alessandra Naves. Gestação de substituição: direito a ter um filho. Revista Ciências Jurídicas e Sociais-UNG-Ser, v. 1, n. 1, p. 50-67, 2011. 
SILVA, Jana Maria Brito. Aspectos polêmicos sobre a gestação de substituição. Publicado em http://www.fa7.edu.br/recursos/imagens/File/direito/ic/v_encontro/aspectospolemicos sobreagestacao.pdf. 2009. Acesso em 13 de jun. de 2019.

SOUZA, Marise Cunha de. As técnicas de reprodução assistida. A barriga de aluguel. A definição da maternidade e da paternidade. Bioética. Revista da EMERJ, v. 13, n. 50, p. 350351, 2010.

TEIXEIRA, Caroline Rocha Pereira. A maternidade de substituição e o conflito de presunção de maternidade certa: estudo de casos. Revista de Doutrina e Jurisprudência, v. 108, n. 1, p. 125-144, 2017.

VENOSA, Sílvio de Salvo. Direito civil: família. - 17. ed. - São Paulo: Atlas, 2017. 